\title{
CARBON-14 DATING IN PISA
}

\section{G. FERRARA, M. REINHARZ, and E. TONGIORGI}

Istituto di Antropologia e Paleontologia Umana, Università di Pisa

\section{INTRODUCTION}

About three years ago a laboratory was set up in Pisa for the study of geologic and paleontologic problems with the help of modern nuclear techniques. The two main items of the first program were the construction of a mass spectrometer for paleotemperature measurements and of a carbon-14dating apparatus.

Financial support for the construction and equipment of this laboratory was given to the University of Pisa by the Administrative Councils of the towns and provinces of Pisa, Livorno, and Lucca. At present the laboratory has increased its activities by welcoming and housing also the Laboratory of Nuclear Geology of the Comitato Nazionale per le Ricerche Nucleari (C.N.R.N.). The construction of the mass spectrometer and carbon-14-dating apparatus was made possible by the generous collaboration of the Physical Institute of the University of Genoa. The Society "Terni" has kindly supplied the necessary iron for the construction of the $\mathrm{C}^{1 . t}$ shield.

Our carbon apparatus was put into use about a year ago. Together with a short description of our experimental setup, our first carbon dates are given here, including measurements of charcoal, wood, and some shell samples. The measurements of shell samples will be reviewed in a later article.

Counter design and electronic apparatus.-Our counter is made of a rectified stainless steel tube with a diameter of $6.5 \mathrm{~cm}$ and has a total capacity of about 1.8 liters. The tungsten central wire of $0.1 \mathrm{~mm}$ diameter is fastened to two Pyrex insulators which close the counter by means of O-ring seals. The metal leads for the attachment of the central wire are soldered to the Pyrex insulators with Araldit. Care has been taken to obtain centering of the wire within $0.1 \mathrm{~mm}$. A gas pressure up to 5 atmospheres can be used. The proportional counter is surrounded by 18 G.M. counters for anti-coincidence shielding. The whole arrangement is placed in an iron shield of about $30 \mathrm{~cm}$ thickness.

The electronic apparatus, constructed wholly by ourselves, consists of a negative high roltage supply up to 9000 volts, a linear amplifier with a maximum amplification of 20,000 , an integral discriminator, the usual anti-coincidence arrangement, and a scaler. Overloading of the amplifier by large impulses is avoided by limiting all impulses greater than 1.2 volts at the entrance of the second feed-back loop. The amplifier has, at an amplification of 10.000 , an output noise of about 0.5 volts. The counting rate of the Geiger counters, arranged in two separate channels, can be controlled on two integrating instruments.

Filling gas.-The filling tube of the proportional counter is connected directly to the chemical line which we built originally to allow the preparation of two counting gases, acetylene and $\mathrm{CO}_{2}$, independently. Our preparation method of $\mathrm{CO}_{2}$, as well as results obtained, will be described in a later article, 
as we are still working on it. All the dates given in this article have been obtained with acetylene counting.

We encountered no difficulties with acetylene prepared as described by Suess (1954). Charred wood samples are treated in the usual manner before combustion and subsequent preparation of the carbide. Wood samples are first carbonized in a hard glass tube in order to avoid deposition of the heavy combustion products in the combustion line. We have compared, with our mass spectrometer, the $\mathrm{C}^{13} / \mathrm{C}^{12}$ ratio of $\mathrm{CO}_{2}$ obtained in a complete combustion with $\mathrm{CO}_{2}$ obtained after carbonizing the wood sample, and we have not found any important difference.

Shells are first washed in dilute $\mathrm{HCl}$ for a few seconds and then crushed and roasted in a stream of oxygen at a temperature of $400^{\circ} \mathrm{C}$ for about one hour in order to burn the organic matter. The $\mathrm{CO}_{2}$ is then liberated with acid and passes through an acid solution of $\mathrm{KMnO}_{4}$ before absorption in ammonia.

In order to obtain about 2 liters of acetylene at a filling pressure of 720 $\mathrm{mm}$, we found it necessary to use $60 \mathrm{~g}$ of strontium carbonate for the preparation of the carbide. This indicates a rather low yield, the reason for which we do not fully understand. We have, however, controlled the constancy of our gas yield. The gas prepared in this way was found to be radioactive due to radon and required storage for about one month before measurement.

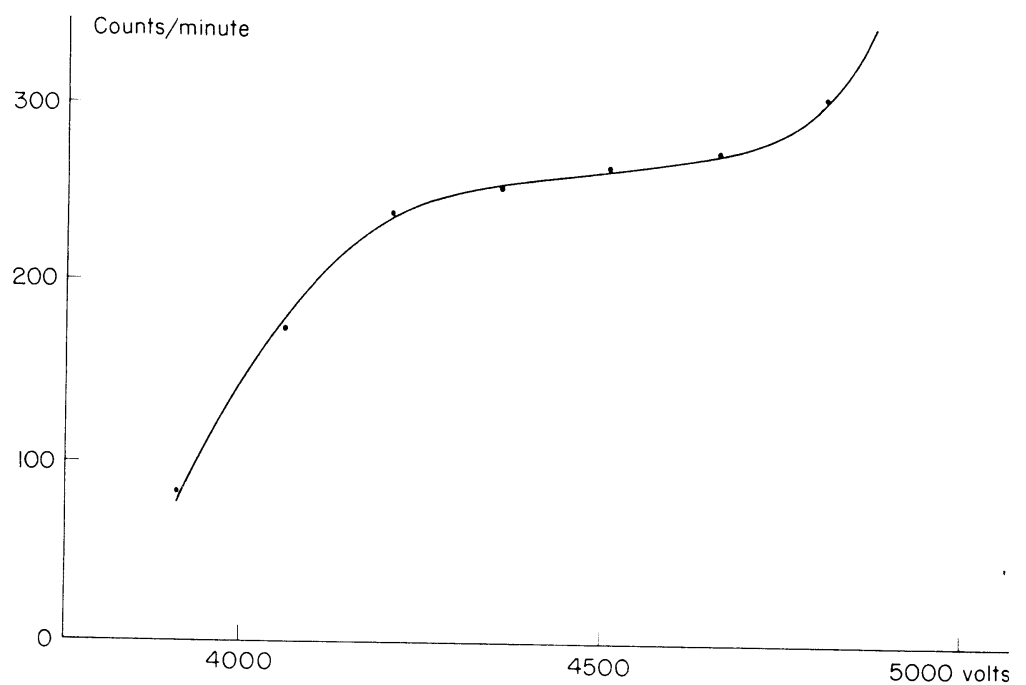

Fig. 1. Meson activity as observed in the proportional counter filled with $\mathrm{C}_{2} \mathrm{H}_{2}$ at a pressure of $720 \mathrm{~mm}$.

Experimental procedure.-A gas pressure of $720 \mathrm{~mm}$ is used in all cases in which a sufficient quantily of sample is arailable. We are working with an amplification of 10,000 and a discriminator setting corresponding to $2 \mathrm{mv}$ at the input of the amplifier. A typical counter characteristic for the meson activity is shown in figure 1 . Our plateaus are generally about 300 volts long and have a slope of less than $0.03 \%$ per volt. The plateau is determined every time before measuring a sample in order to be sure that our working point has 
remained unchanged. The total Geiger count, which in our case is about 2800/ min. is determined before and after each measurement.

Our background is 20 counts $/ \mathrm{min}$ and the net effect for the living sample 19.2 counts/min. The hackground, which is rather high in comparison with what has been obtained by other stations (see Olsson, 1957), is probably due to the counter material. We have another counter in construction which we hope will give us a considerably lower background. The fluctuations in the background counts are rather small, as can be seen from Table A in which 12 background measurements made in a period of 2 months are set forth.

All samples are measured for at least 24 hours; the background is counted after every four sample measurements. The register of the scaler counting the proportional counter impulses, as well as the integrating instruments for the Geiger count, are photographed every hour. The counts per hour are then analyzed statistically to insure that the variations are within statistical limits. The errors given are standard deviations, the contributions of the background and of the living sample to the statistical error are included. Our error does not include a possible error in the half-life of $\mathrm{C}^{14}$. Because of the Suess effect (Suess, 1953), all ages are too low, but a correction will be applied as soon as a value for the living sample has generally been agreed on.

TABLE A

Background measurements made with gas from three different preparations (marble, shells, and coal) during two months.

\begin{tabular}{|c|c|c|}
\hline & Date & Background, counts/min \\
\hline January & 7,1958 & 19.80 \\
\hline$"$ & 16,1958 & 19.82 \\
\hline$"$ & 26,1958 & 20.10 \\
\hline$"$ & 31,1958 & 20.21 \\
\hline ebruary & 3,1958 & 20.21 \\
\hline$"$ & 5,1958 & 20.27 \\
\hline$"$ & 7, 1958 & 20.09 \\
\hline$"$ & 9,1958 & 19.85 \\
\hline$"$ & 14,1958 & 20.27 \\
\hline$"$ & 16,1958 & 20.10 \\
\hline$"$ & 22,1958 & 20.25 \\
\hline$"$ & $\begin{array}{r}26,1958 \\
\text { Mean: }\end{array}$ & \pm 0.04 \\
\hline
\end{tabular}

The archaeologic samples are given in Table $I$, and geologic samples in Table II. All ages are given in radiocarbon years B.P.

For the value of the living shell we have chosen the mean of three measurements listed in Table B, obtaining a mean of 1.02. We have calculated the ages of all shell measurements hy multiplying the recent wood count by 1.02 .

$\begin{array}{ccc} & \text { T'ABI.E B } & \\ \text { Species } & \text { Ratio of living shell count } & \\ & \text { to recent wood count } & \text { Provenience } \\ \text { Patella coerulea } & 1.016 & \text { Livorno } \\ \text { enus gallina } & 1.009 & \text { Viareggio } \\ \text { urex brandaris } & 1.028 & \text { Gaeta }\end{array}$




\section{Pi-23. Grotta di Ortucchio, Italy}

Charcoal found in 1957 by A. M. Radmilli during excavation of a deposit in Ortucchio Cave, $20 \mathrm{~km} \mathrm{SE}$ of Avezzano, Abruzzo (41. $57^{\prime} \mathrm{N}$ Lat, $13^{\circ} 39^{\prime}$ E Long). The remains of food consist of bones of birds and small mammals, nearly all young individuals, evidently captured with traps. This has led to the assumption that the cave was inhabitated by men with a Mesolithic culture. The stone industry is slightly different from that of the Upper Paleolithic in the same region, which, however, is always found together with remains of food consisting of bones of large mammals (Cervus, Equus, Sus, Bos). The sample having been taken in the lowermost part of the cultural layer, the carbon date can be considered representative of a rather early phase in the acquisition of the new form of economy (early Mesolithic). The hearth from which the sample has been taken was covered by $2 \mathrm{~m}$ of earth with some stones. The deposit continues for many meters underneath. Subm. by A. M. Radmilli, Museo Preistorico L. Pigorini, Roma.

\section{Pi-10. Grotta La Porta, Italy}

$8619 \pm 200$

Shells (Patella) found in 1956 during excaration by A. M. Radmilli in La Porta Cave, $500 \mathrm{~m}$ E of Positano, Campania $\left(40^{\circ} 38^{\prime} \mathrm{N}\right.$ Lat, $14^{\circ} 29^{\prime} \mathrm{E}$ Long). The shells, present in the deposit in great quantity, represent remains of food and characterize the Mesolithic economy of the settlements on the sea coast, (Radmilli and Tongiorgi, 1958). The layer from which the sample was taken. about $1 \mathrm{~m}$ beneath the surface, consists of red earth washed in from the outside, mixed with ashes from hearths. At present the cave is completely dry; in the past, however, water dripping from the cave top has deposited a layer of dripstone on the surface of the deposit; the water, however, did not penetrate the layer containing the shells. These are perfectly preserved, without incrustations and with a high content of organic substance. Subm. by A. M. Radmilli, Museo Preistorico L. Pigorini, Roma.

\section{Pi-28. Petescia, Italy}

$5398 \pm 145$

Carbonized acorns from the Middle Neolithic layer, at a depth of about $4.5 \mathrm{~m}$ in the colluvium accumulated in Ottara Valley at Petescia, $2 \mathrm{~km} \mathrm{NE}$ of Cittaducale, Lazio $\left(42^{\circ} 24^{\prime} \mathrm{N}\right.$ Lat, $12^{\circ} 59^{\prime} \mathrm{E}$ Long $)$. The deposit consists mostly of red earth alternating with layers containing many stones. The acorns were found during an excavation in 1951 conducted by M. O. Acanfora. Museo Preistorico I. Pigorini, Roma, who sulmitted the sample (A'anfora, 1956).

\section{Isola Virginia series, Italy}

Wooden platform of a lake dwelling constructed at the time of the first human settlement during the Middle Neolithic period in Virginia Island, Lake of Varese, Lombardia $\left(45^{\circ} 19^{\prime} \mathrm{N}\right.$ Lat, $10^{\circ} 43^{\prime} \mathrm{E}$ Long). Excavation in 1956 1957 by M. Bertolone, Museo Civico, Varese, from whom the samples were obtained. For some preliminary notes on the archaeologic site see Mirabella Roberti (1955) and Bertolone (1957).

\section{Pi-4. Isola Virginia 1}

Part of a great trunk underneath the wooden layer forming the platform. 
The wood, perfectly preserved, was contained in a layer consisting mostly of plant materials accumulated by men during the construction of the platform. The latter is covered with about $20 \mathrm{~cm}$ of clay followed by another cultural layer of black earth of an age not very different from that of the platform underneath. A layer of sandy earth separates the more ancient layers from the recent humus. Pollen analysis (Durante Pasa, 1955) shows a maximum of Abies in the layer from which the sample has been taken, followed in the direction of the surface by an increased amount of Quercus and then by a new maximum of Abies. At the base of the sandy layer Pinus and Quercus start to increase.

Pi-38. Isola Virginia 2

Sample taken from the wooden floor of the platform immediately beneath the clay layer.

\section{Pi-15. Phaestos, Crete}

Average: $\mathbf{3 4 7 5} \pm \mathbf{8 6}$

Charcoal from a beam which, from its stratigraphic position, is thought to have belonged to the First Palace charred during the burning of the building (Levi, 1956). It is not clear whether the wooden structure belonged to the first, or, more likely, to the second architectural phase. In any case the radiocarbon date is about $300 \mathrm{yr}$ younger than expected on the base of the current archaeologic chronology. The charcoal sample was kept for about 3 years without special care, but, as it consisted of large pieces, contamination with recent carbon seems improhable. The sample was measured twice with gas from two independent preparations. Subm. by C. Gerra, Scuola Archaeologica Italiana, Athens.

Pi-15A.

$3470 \pm 120$

Pi-15B.

$3480 \pm 120$

\section{Isolone del Mincio series, Italy}

An island formed at the site of an ancient lake dwelling which had been constructed in the Mincio River $4 \mathrm{~km} \mathrm{E}$ of Volta Mantovana (Mantova), Lombardia $\left(45^{\circ} 19^{\prime} \mathrm{N}\right.$ Lat, $10^{\circ} 43^{\prime} \mathrm{E}$ Long). The surface layer consists of stones and some sand with little vegetation. The archaeologic layer underneath consists of sandy earth rich in organic matter containing ceramic and bronze objects pertaining to a culture following the Polada culture. This layer is at present beneath the low-water level of the river. Excavated by the "Soprintendenza anlichita della Lombardia”, 1956 (Mirabella Roberti, 1950b). Samples subm. by F. Rittatore, Cabinetto di Paletnologia e Paleontologia Umana dell' Università, Milano.

Pi-25. Isolone del Mincio 1

$3333 \pm 115$

Part of a wooden paling from the first phase of habitation of the lake dwelling.

Pi-26. Isolone del Mincio 2

$3100 \pm 113$

Portion of a trunk from the third phase of habitation of the lake dwelling.

\section{Pi-18. Torre Paola, Italy}

$2176 \pm 105$

Shells (Murex) found in a shell heap on the southern slope of Mount 
Circeo, Lazio $\left(41^{\circ} 13^{\prime} \mathrm{N}\right.$ Lat, $13^{\circ} 2^{\prime} \mathrm{E}$ Long). The shells represent remains from a purple-extracting industry of the lst century B.c. The shell heap is now covered with only little sand and is exposed to rain and to runoff over the calcareous mountain slopes. The sample was measured to see how much the date of a shell sample, preserved under unfavorable conditions, differs from the expected one. Subm. by E. Tongiorgi.

\section{Pi-22. Baratti, Italy}

Wood from a wrecked ship buried in $\quad 1847 \pm \mathbf{1 0 5}$ cana $\left(43^{\circ} 0^{\prime} \mathrm{N}\right.$ Lat, $10^{\circ} 30^{\prime} \mathrm{E}$ Loried in bottom clay of Bay of Baratti, TosEtruscan archaeologic material Long). Due to the richness of the Roman and ascertain a been dated to ascertain whether it would be of interest to remove the clay and possibly recover the ship. Since the sample was in a very poor state of preservation, full of marine fauna, we are not sure that we have eliminated all contamination with recent carbon. Our date, therefore, gives only a lower limit. Subm. by A. Olschki and G. Marinelli, Istituto di Mineralogia dell'Università, Pisa.

\section{Fiumicino series, Italy}

Wood, and a related shell sample, from the Port of Fiumicino, $7 \mathrm{~km} \mathrm{~W}$ of Ostia (Roma), Lazio (41 $46^{\prime} \mathrm{N}$ Lat, $12^{\circ} 15^{\prime} \mathrm{E}$ Long), built by the Roman emperor Claudius ( 10 B.C. to 54 A.D.). Sample Pi-3A was well preserved wood from one of the boards of the frame used in constructing a pier, coll. 1957 Sample Pi-3B was shell (Mactra) from the excave exation directed by G. Iacopi. ably differs was shell (Mactra) from the same excavation, and its date probMuseo Preistorico L. Pioring the construction. Subm. by A. M. Radmilli,

Pi-3A. Fiumicino 1, Wood

Pi-3B. Fiumicino 2, Shell

\section{GEOLOGIC SAMPLES}

\section{Pi-6. Fuersteiner, Switzerland}

$10,178 \pm 400$

Tree stump exposed by an ancient landslide, and dating an epipaleolithic culture at Burgäschisee $\left(47^{\circ} 11^{\prime}\right.$ N Lat, $7^{\circ} 39^{\prime} 40^{\prime \prime}$ E Long), near Seeberg, Canton Bern. Sample dated also by H. Oeschger, Physics Institute, University
of Bern, as B-16, 10,200 \pm 200 (Oeschger, 1959).

\section{Pi-5. Molveno, Italy}

Tree trunk from a submerged fore Lake Molveno, $15 \mathrm{~km}$ NW of the wood anatomy, of leaverto $\left(46^{\circ} 07^{\prime} \mathrm{N}\right.$ Lat, $10^{\circ} 57^{\prime} \mathrm{E}$ Long). A study $20 \%$. Picea Quercus, Aluus, Tus, seeds, and pollen grains (Fagus 40\%, Abies dominance of Fagus, which spread through the cach about $6 \%$ ) shows a prening of the Bronges, which spreatd through the region of Trento at the begin1000 to 800 B.ce Age. Its maximum, hased on archaeologic evidence, is about the other hand, the forest of Iron Age pottery seem to confirm this date. On the other hand, the forest is certainly pre-Roman, since the existence of the lake in the Roman period seems established. Subm. by V. Marchesoni, Museo 


\section{Pi-19. St. Michel en l'Herm, France}

$892 \pm 100$

Shells (Ostrea) from two large shell heaps (now almost completely destroyed) situated at St. Michel en l'Herm, Dept. Vendée $\left(46^{\circ} 22^{\prime} \mathrm{N}\right.$ Lat, $1^{\circ}$ $15^{\prime} \mathrm{W}$ Long), about $7 \mathrm{~km}$ from the present coast; indicated on the Geologic Map of France (Sheet 141 SO: Fontenay Le Compte) as "buttes des chaudes". When the sample was sent in November, 1957, the stratigraphic position and consequently the age of the deposit were still under discussion. After the measurement was done, M. Ters communicated that a test pit, as well as further observations made at the same time, have led him to interpret the deposit as of artificial origin. The deposit is now thought to be a dump of an oyster-packing industry probably set up by the monks of the abbey of St. Michel en l'Herm. Coins from 11th to 13th centuries found in Ostrea heaps confirm our date. The deposit was not covered and was consequently exposed to weather, especially to sea winds, which are very strong in this region. Coll. 1957 and subm. by M. Ters, 72 Rue Henri Regnault, Saint Cloud (Seine et Oise), France.

\section{Pi-20. La Caserne, France}

$1968 \pm 110$

Shells (Ostrea) inclosed in mud from beneath the river bed of the Sèvre Niortaise $2 \mathrm{~km}$ from the estuary (geologic map: the same as for the previous sample, $10 \mathrm{~km} \mathrm{E}$ of Marans, Vendée) $\left(46^{\circ} 18^{\prime} \mathrm{N}\right.$ Lat, $0^{\circ} 48^{\prime} \mathrm{W}$ Long). State of preservation better than $\mathrm{Pi}-19$. The $\mathrm{C}^{14}$ date indicates that the altitude of the river bed has remained essentially the same since the Gallo-Roman period. Subm. 1957 by M. Ters, Saint Cloud, France.

\section{Plain of Pisa series, Italy}

Samples obtained from borings made in the search for water. The study of numerous borings from the sedimentological point of view as well as the study of the microfauna and pollen grains has allowed reconstruction of the history of the formation of the plain. This study will soon be published by E. Tongiorgi and collaborators. All samples subm. by E. Tongiorgi.

Pi-7A. Piazza del Duomo, Pisa 1

$26,364 \pm 1405$

Shells (Cardium) from depth $30 \mathrm{~m}$ in a boring in the square of the Cathedral of Pisa $\left(43^{\circ} 43^{\prime} \mathrm{N}\right.$ Lat, $10^{\circ} 24^{\prime} \mathrm{E}$ Long). The level, in which pollen grains of Pinus and Abies are dominant with very little Quercus, is near the bottom of a thick layer of lagoon clay, underlying a level interpreted as due to lowering of sealevel during Würm III. Before the formation of the lagoon the plain was covered by dunes; in these dunes $15 \mathrm{~km}$ NNW of Pisa at Torre del Lago (Blanc, Settepassi, and Tongiorgi, 1953), Mousterian industry has been found.

Pi-7B. Piazza del Duomo, Pisa 2

$6892 \pm 260$

Shells (Cardium) from depth $11.5 \mathrm{~m}$ in the same horing as $\mathrm{Pi}$-7A, at a level near the top of the lagoon clay, with pollen grains of Quercus (dominant), Abies, and Alnus between two levels in which nearly all the pollen grains belong to Pinus. The depth of deposits of this climatic phase, with Quercus dominant, easily recognized in pollen analyses, has been used to determine the value of the subsidence in the various points of the plain. 
Pi-21. Tombolo

$6659 \pm 153$

Shells of various species in a beach sediment at depth $22 \mathrm{~m}, 7.5 \mathrm{~km} \mathrm{SW}$ of Pisa ( $43^{\circ} 40^{\prime} \mathrm{N} \mathrm{Lat}, 10^{\circ} 20^{\prime} \mathrm{E}$ Long), about halfway between Pisa and the present coast. The sediment was deposited at the end of the climatic phase of $\mathrm{Pi}-7 \mathrm{~B}$, as demonstrated by pollen analysis.

\section{Pi-35. Marina di Torre del Lago}

$\mathbf{8 9 4 0} \pm \mathbf{2 7 3}$

Shells of various species found at depth $47 \mathrm{~m}, 16 \mathrm{~km} \mathrm{NW}$ of Pisa $\left(43^{\circ} 49^{\prime}\right.$ $\mathrm{N}$ Lat, $10^{\circ} 16^{\prime}$ E Long), about $400 \mathrm{~m}$ from the present coast.

\section{Pi-13. Pontedera}

$3767 \pm 115$ the town of Pontedera $\left(43^{\circ} 40^{\prime}\right.$ construction of a canal at depth $2 \mathrm{~m}$ near numerous tree trunks was contan $\mathrm{N}$ Lat, $10^{\circ} 38^{\prime} \mathrm{E}$ Long). The sample with other characterized by an increantained in alluvial sand deposed in a climatic phase domint dominant and the zone was a lagoon.

\section{Pi-30. Lavandone}

Shells (Cardium) found at depth $1 \mathrm{~m}$. The sample, deposited a little later than the climatic phase of $\mathrm{Pi}-13$, indicates the date of the end of the lagoon in this locality, $11 \mathrm{~km} \mathrm{~S}$ of Pisa ( $43^{\circ} 37^{\prime} \mathrm{N}$ Lat, $10^{\circ} 25^{\prime} \mathrm{E}$ Long). The lagoon, more and more reduced, became the Port of Pisa in Roman and later times.

\section{REFERENCES}

Acanfora, M. O., I depositi preistorici di Valle Ottara (Petescia) presso Cittaducale: Internat. Quaternary Assoc. Cong., 4th, Rome-Pisa 1953, Actes, v. 2, p. 759-765.

Bertolone, M., 1957, Recenti ricerche del Centro di studi preistorici e archeologici di Varese: Riv. Sci. Preist., v. 12, p. 125.

Blanc, A. C., Settepassi, F., and Tongiorgi, E., 1953, Excursion au Lac de Massaciuccoli (Plaine côtière de la basse Versilia) : Internat. Quaternary Assoc. Cong., 4th, Rome-
Pisa 1953, Livre Guide, p. 1-29.

Durante Pasa, M. V., 1955, Saggio di analisi pollinica nei depositi olocenici dell'isola Virginia (Lago di Varese) : Sibrium, v. 2, p. 237-242 Levi, D., 1956, Attività della scuola Archeologica Italiana di Atene nell'anno 1955: Boll.
Arte, pt. 3, p. 238 .

Marchesoni, V., 1954, Il lago di Molveno e la foresta riaffiorata in seguito allo scavo: Studi Trentini Sci. Nat., v. 31, p. 9-24.

Mirabella Roberti, M., 1955, Biandronno (Varese) : Riv. Sci. Preist., v. 10, p. 154. 1956a, Biandronno (Varese) : Riv. Sci. Preist., v. 11, p. 244.

e lettere. Conv, di studi pera fluviale a Sud di Valleggio sul Mincio: Ist. Lombardo sci. e lettere. Conv. di studi per rapp. sci. culturali italo-svizzeri Atti (Comitato italiano per le celebrazioni del $50^{\circ}$ amnicersario del Iraforo del Sempione), p. 118.

Ser. Rabio, Sure, U., and Gfeller, (hr., 1959, Bern radiocarbon dates I: Aм. Jour.

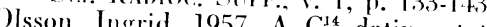

Arkiv för Fysik, v. 13, $\mathrm{C}^{14}$ dating stalion using the $\mathrm{CO}_{2}$ proportional counling method:

Radmilli, A. M., and Tongiorgi, E., 1958, Gli scavi nella grotta "La Porta" a Positano: Contributo alla conoscenza del mesolitico Italiano: Riv. Sci. Preist., v. 13, p. 90-108.

tween the atmosphere and the searbon and the rate of exchange of carbon dioxide beconference on Research Council, Comm on Research Council, Comm. on Nuclear Sci., v. 1, 82 \%.

p. $5-7$. 